\title{
Purification and Identification of an FMN-dependent NAD(P)H Azoreductase from Enterococcus faecalis
}

\author{
Sumit Punj and Gilbert H. John* \\ Department of Microbiology and Molecular Genetics, 307, \\ Life Science East, Oklahoma State University, Stillwater, \\ OK, 74078, USA
}

\begin{abstract}
Azoreductases reduce the azo bond $(\mathrm{N}=\mathrm{N})$ in azo dyes to produce colorless amine products. Crude cell extracts from Enterococcus faecalis have been shown to utilize both NADH and NADPH as electron donors for azo dye reduction. An azoreductase was purified from $E$. faecalis by hydrophobic, anion exchange and affinity chromatography. The azoreductase activity of the purified preparation was tested on a polyacrylamide gel after electrophoresis under native conditions and the protein that decolorized the azo dye (Methyl Red) with both NADH and NADPH was identified by mass spectrometry to be AzoA. Previously, the heterologously expressed and purified AzoA was shown to utilize NADH only for the reduction of Methyl Red. However, AzoA purified from the wild-type organism was shown to utilize both coenzymes but with more than 180-fold preference for NADH over NADPH as an electron donor to reduce Methyl Red. Also, its specific activity was more than 150 -fold higher than the previous study on AzoA when NADH was used as the electron donor. The catalytic efficiency for Methyl Red reduction by AzoA from E. faecalis was several orders of magnitude higher than other azoreductases that were purified from a heterologous source.
\end{abstract}

\section{Introduction}

Azoreductases are enzymes that reduce the azo bond $(\mathrm{N}=\mathrm{N})$ in azo dyes to produce colorless amine products (Stolz, 2001). These dyes are widely used in the paper, textile, food, cosmetic and pharmaceutical industries and are regarded as environmental pollutants and a danger to human health due to their role in carcinogenesis (Chen, 2006; Chung et al., 1992; Stolz, 2001).

Although azo dyes are anthropogenic, azo dye reduction is observed in many organisms by enzymes which include the rat liver enzyme, cytochrome P450 (Zbaida and Levine, 1990), rabbit liver aldehyde oxidase (Stoddart and Levine, 1992) and azoreductases from the intestinal microbiota, environmental bacteria and fungi (Chen, 2006) as well as halotolerant and halophilic organisms (Asad et al., 2007).

Bacterial azoreductases from different organisms are diverse and variations can exist among the same organism (Ghosh et al., 1992). Classification of azoreductases based on their primary amino acid level is difficult due to

"Corresponding author: Email: gilbert.john10@okstate.edu Phone: +1 405744 7914; Fax: +1 4057446790. low homology. However, a classification scheme based on the secondary and tertiary amino acid analysis has been developed (Abraham KJ, 2007). Based on function, another classification scheme is used in which azoreductases are categorized as either flavin-dependant azoreductases (Chen et al., 2005; Chen et al., 2004; Nakanishi et al., 2001) or flavin-independent azoreductases (Blumel et al., 2002; Blumel and Stolz, 2003). The flavin-dependent azoreductases are further organized into three groups; NADH only (Chen et al., 2004; Nakanishi et al., 2001), NADPH only (Chen et al., 2005) or both (Ghosh et al., 1992; Wang et al., 2007), as these coenzymes serve as electron donors.

Enterococcus faecalis is a Gram-positive opportunistic pathogen present in the intestine of mammals. The heterologously expressed and purified azoreductase, AzoA has been characterized (Chen et al., 2004) and crystallized (Liu et al., 2007). According to Chen et al., AzoA is an FMNdependent azoreductase that can use only NADH as an electron donor. However, our studies (Punj and John, 2008) on crude cell extracts from wild-type as well as previous studies (Walker et al., 1971) have shown that azoreductase activity involves NADPH as well as an electron donor. This observed activity could be due to the presence of other $\mathrm{NADPH}$-specific azoreductases or altered activity caused by the heterologously expressed enzyme.

The current study focuses on the purification and mass spectrometry-based identification of a native azoreductase (AzoA) from E. faecalis. It is the first study to show a qualitative polyacrylamide-based enzyme assay under aerobic conditions for an azoreductase isolated from a human intestinal bacterium. The pseudo first order kinetic rates of AzoA using NADH, NADPH, FMN and Methyl Red as substrates are described and the catalytic efficiency of the wild-type purified AzoA is compared to other azoreductases purified from a heterologous source.

\section{Materials and Methods}

E. faecalis ATCC 27274 was grown in Brain Heart Infusion (BHI) medium (Difco Laboratories, Spark, MD, USA). For long term storage, $16 \%$ glycerol stocks of the organism were prepared and stored at $-80{ }^{\circ} \mathrm{C}$. Methyl Red (MCB Chemicals, Norwood, Ohio, USA; molecular weight, 269.31, $2\left[4-\left(\mathrm{CH}_{3}\right)_{2} \mathrm{NC}_{6} \mathrm{H}_{4} \mathrm{~N}: \mathrm{N}\right] \mathrm{C}_{6} \mathrm{H}_{4} \mathrm{CO}_{2} \mathrm{H}$, CAS registry 63451-28-5) was used as the azo dye under investigation. $\mathrm{NAD}(\mathrm{P})$ $\mathrm{H}$ (> 99\% purity) was from Calbiochem (San Diego, CA, USA) and FMN was from Sigma (St. Louis, MO, USA). Chromatography resins used were Octyl Sepharose ${ }^{\mathrm{TM}} 4$ Fast flow from Amersham Biosciences (Piscataway, NJ, USA) and DEAE Bio-Gel ${ }^{\circledR}$ agarose 100-200 mesh and Affi-Gelß Blue Gel 100-200 mesh from Bio-Rad (Hercules, CA, USA). The chromatography columns used for hydrophobic interaction chromatography and ion exchange 
chromatography were Flex-Column ${ }^{\circledR}$ from Kimble/Kontes (Vineland, NJ, USA)

\section{Purification of azoreductase}

Preparation of cell extracts: A single colony of $E$. faecalis grown on a $\mathrm{BHI}$ plate was used to inoculate $5 \mathrm{~mL}$ of $\mathrm{BHI}$ broth. The culture was grown at $37{ }^{\circ} \mathrm{C}$ for $12 \mathrm{~h}$ and $1 \mathrm{~mL}$ was transferred to $20 \mathrm{~L}$ of $\mathrm{BHI}$ broth. The $20 \mathrm{~L}$ culture was incubated at $37^{\circ} \mathrm{C}$ until an $\mathrm{OD}_{600}=0.9$ (late log phase) was reached. The cells were harvested at $6000 \times \mathrm{g}$ for $10 \mathrm{~min}$ at $4{ }^{\circ} \mathrm{C}$. The bacterial pellet was resuspended in buffer A (50 $\mathrm{mM}$ potassium phosphate buffer, $\mathrm{pH} 7$ ).

Lysozyme and DNase I were added at final concentrations of $1 \mathrm{mg} \cdot \mathrm{mL}^{-1}$ and $10 \mu \mathrm{g} \cdot \mathrm{mL}^{-1}$ respectively, and the sample was incubated at $37{ }^{\circ} \mathrm{C}$ for $20 \mathrm{~min}$. The sample was sonicated (probe diameter $=2 \mathrm{~cm}$ ) on ice at $60 \%$ output using a Sonic 300 Dismembrator (Artek systems corporation, farmindale, NY, USA) for a total of 6 min with $20 \mathrm{~s}$ pulses and phenylmethanesulphonylfluoride (PMSF, $1 \mathrm{mM}$ final concentration) was immediately added. The lysate was clarified by centrifugation at $100,000 \times \mathrm{g}$ for $30 \mathrm{~min}$ at $4{ }^{\circ} \mathrm{C}$ and the pellet was discarded. Ammonium sulfate was added at $4{ }^{\circ} \mathrm{C}$ to the clarified cell extract to a final concentration of $0.5 \mathrm{M}$ and EDTA was added to a final concentration of 0.5 $\mathrm{mM}$. Note: All subsequent purifications steps were carried out at $4^{\circ} \mathrm{C}$.

Hydrophobic Interaction Chromatography (HIC): The sample was applied at a linear flow rate of $8.5 \mathrm{~cm} \cdot \mathrm{h}^{-1}$ to an octyl sepharose 4 flast flow column $(2.5 \times 15.5 \mathrm{~cm})$ that was equilibrated with buffer $B$ ( $50 \mathrm{mM}$ potassium phosphate buffer, pH 7; $0.5 \mathrm{mM}$ EDTA; $0.5 \mathrm{M}$ ammonium sulfate). After applying the sample, the column was washed with two volumes of $25 \mathrm{mM}$ potassium phosphate buffer, $\mathrm{pH} 7$ and the bound protein was eluted with $30 \%$ isopropanol. The eluted protein was concentrated to $20 \mathrm{~mL}$ and diafiltrated with $200 \mathrm{~mL}$ of buffer $\mathrm{C}(10 \mathrm{mM}$ Tris- $\mathrm{Cl}, \mathrm{pH} 8$, the $\mathrm{pH}$ of Tris- $\mathrm{Cl}$ was adjusted at $4{ }^{\circ} \mathrm{C}$ with $\mathrm{HCl}$ ) in an ultrafiltration cell (Amicon Inc., Beverly, MA, USA) using a 10,000 NMWL membrane (Millipore Corporation, Bedford, MA, USA).

Ion Exchange Chromatography (IEX): The sample was diluted with buffer $\mathrm{C}$ to obtain a final protein concentration of $7.5 \mathrm{mg} \cdot \mathrm{mL}^{-1}$ and applied at a linear flow rate of $7 \mathrm{~cm} \cdot \mathrm{h}^{-1}$ to a DEAE Bio-gel agarose column $(2.5 \times 10.5 \mathrm{~cm})$ which was previously equilibrated with buffer $C$. The column was washed with $300 \mathrm{~mL}$ of buffer C. The protein was eluted with $300 \mathrm{~mL}$ of buffer $\mathrm{C}$ containing a linear gradient of $\mathrm{NaCl}$ from $0-200 \mathrm{mM}$. The fractions $(6 \mathrm{~mL}$ each) that had the highest azoreductase activity were pooled together and concentrated to $11 \mathrm{~mL}$.

Affinity Chromatography: The pooled and concentrated sample was applied at a linear flow rate of $9 \mathrm{~cm} \cdot \mathrm{h}^{-1}$ to Affigel Blue gel $(2 \times 1.5 \mathrm{~cm})$ that was equilibrated with buffer $\mathrm{C}$. The column was washed with $12 \mathrm{~mL}$ of buffer $\mathrm{C}$ containing $1 \mathrm{M} \mathrm{NaCl}$. The bound protein was eluted with $12 \mathrm{~mL}$ of $30 \%$ isopropanol containing $3 \mathrm{M} \mathrm{NaCl}$. The sample was concentrated and diafiltrated with $100 \mathrm{~mL}$ of buffer $\mathrm{A}$. The enzyme fraction was aliquoted and stored at $-20{ }^{\circ} \mathrm{C}$ in $50 \%$ glycerol.
Protein concentration was determined using the Bradford method with bovine serum albumin (BSA) as a standard.

Azoreductase activity assay

Qualitative assay: A preparative mini $5-12.5 \%$ gradient resolving polyacrylamide gel was prepared according to the method by Laemmli (Laemmli, 1970), without the addition of sodium dodecyl sulfate (SDS) using a MiniPROTEAN® II apparatus (Bio-Rad Hercules, CA, USA). The protein sample from the affinity chromatography fraction $\left(0.3 \mathrm{mg} \cdot \mathrm{mL}^{-1}\right)$ was loaded in the single preparative reference well. Electrophoresis was performed at $4{ }^{\circ} \mathrm{C}$ in Tris-glycine buffer, pH 8.3 at 6 milliamps constant current. After electrophoresis, the gel was split down the middle and each half was placed in two shallow trays. To one tray, $5 \mathrm{~mL}$ buffer DH (Tris-Cl, pH 7.5; 0.5 mM Methyl Red; $10 \mu \mathrm{M}$ FMN; $1 \mathrm{mM} N A D H$ ) was added and to the other tray, $5 \mathrm{~mL}$ buffer $\mathrm{DPH}$ (Tris-Cl, pH 7.5; 0.5 mM Methyl Red; $10 \mu \mathrm{M}$ FMN; 2 $\mathrm{mM}$ NADPH) was added. Each tray was incubated for 10 min at room temperature with gentle shaking to assure that solutions were evenly distributed across the gels. After the zones of clearing were observed, the center and the periphery of the clear zone on both gels were marked by a notch and the mobility of the clearing zone calculated. The gels were subsequently directly stained by Coomassie Blue R-250 and using the notch as the reference point, the mobility of the visible protein band was determined. Mobility was calculated as the ratio of the distance of center of clearing zone (protein) to the distance traveled by the tracking dye.

Quantitative assay during purification: The assay was carried out in $1 \mathrm{~mL}$ cuvettes and contained $50 \mathrm{mM}$ phosphate buffer, (pH 7.2); $20 \mu \mathrm{M}$ Methyl Red; $20 \mu \mathrm{M}$ FMN; $0.5 \mathrm{mM}$ $\mathrm{NADPH}$ and an appropriate amount of enzyme $(1-800 \mu \mathrm{g})$. The reaction was initiated by adding NADPH. The enzyme activity was determined by an absorbance reduction in the first $2 \mathrm{~min}$ at $430 \mathrm{~nm}$ for Methyl Red using a UV-Visible spectrophotometer (UV-1601PC, Shimadzu, Columbia, MD, USA). The extinction coefficient for Methyl Red used was $23,360 \mathrm{M}^{-1} \mathrm{~cm}^{-1}$. A unit $(\mathrm{U})$ of azoreductase activity was defined as the amount of enzyme required to reduce 1 $\mu \mathrm{mol}$ per min of Methyl Red.

\section{Protein Identification}

Matrix Assisted Laser Desorption/lonization-Time of Flight (MALDI-TOF): The protein band corresponding to the zone of clearing seen in Fig. 1B was excised and washed with $50 \%$ acetonitrile/25mM ammonium bicarbonate $(\mathrm{pH} 8.0)$. The sample was dehydrated with $100 \%$ acetonitrile and subsequently digested with a solution of

$15 \mu \mathrm{g} \cdot \mathrm{ml}^{-1}$ sequencing-grade trypsin in $25 \mathrm{mM}$ bicarbonate buffer. The peptides were extracted with $0.5 \%$ trifluoroacetic acid (TFA) mixed with $\alpha$-cyano-4-hydroxycinnamic acid and analyzed in reflectron mode using a Voyager-DE ${ }^{\mathrm{TM}}$ PRO Biospectrometry Workstation (PerSeptive Biosystems, Inc., USA). Spectra were deisotoped using a detection threshold that was manually adjusted to exclude spectral noise, and the result peak list was used to search the MSDB database (3239079 sequences) using the Mascot search engine (Matrix Science, London, UK). Search parameters included a statement of 100 ppm mass accuracy and the amino acid 


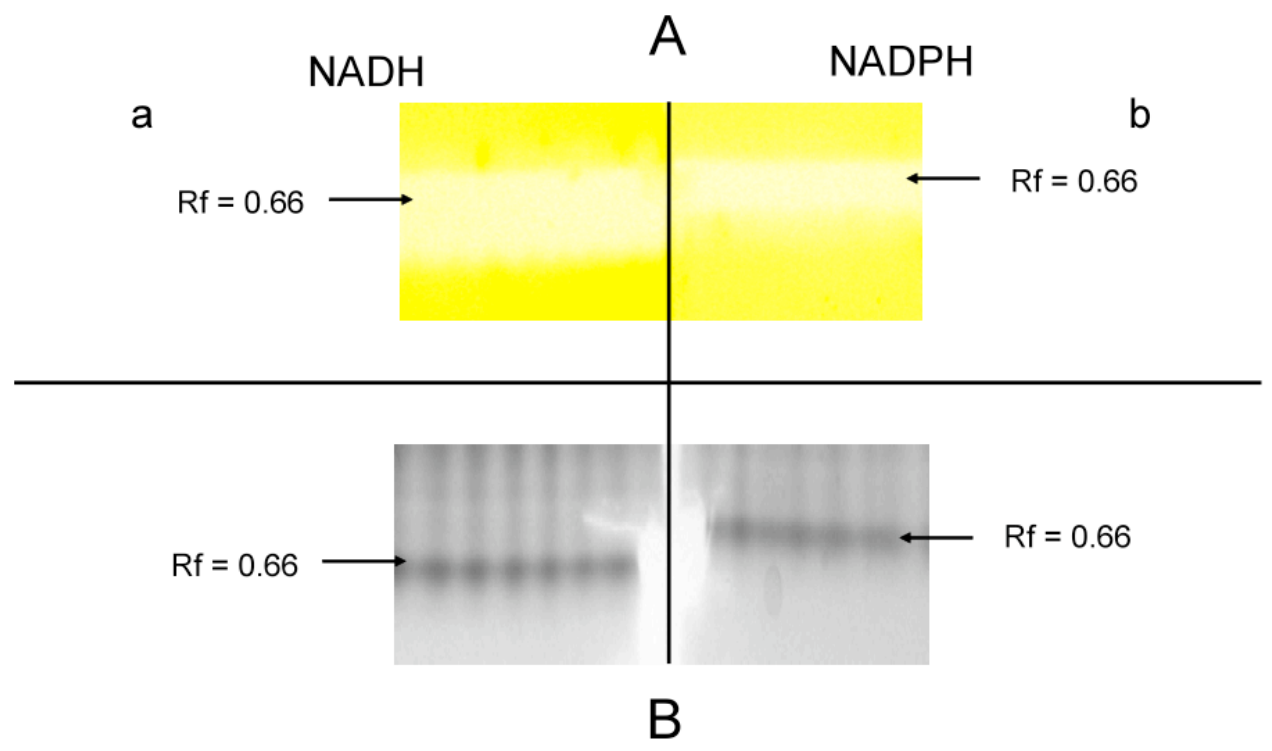

Fig.1 Native gel assay: A) 5-12.5\% gradient native PAGE incubated with 0.5mM Methyl Red + $10 \mu \mathrm{M}$ FMN; a - 1mM NADH, b - 2mM NADPH. Arrows indicate the zone of clearing, B) Gel Aa and Ab stained with Coomassie Blue. Arrows indicate the stained protein band

\author{
Mobility (Rf) = Distance of clearing zone $(A)$ or protein band $(B)$ \\ Distance of tracking dye \\ Note: Gel with single large well was divided in half and incubated in separate conditions
}

modifications: Met oxidation, pyroglutamate cyclization of glutamine, and acrylamide adducts of Cysteine.

Capillary HPLC-electrospray ionization tandem mass spectra (HPLC-ESI-MS/MS): The HPLC-ESI-MS/MS data for the trypsin digested sample were acquired on a Thermo Fisher LTQ linear ion trap mass spectrometer fitted with a New Objective PicoView 550 nanospray interface. On-line HPLC separation of the digests was accomplished with an Eksigent NanoLC micro HPLC: column, PicoFrit ${ }^{\mathrm{TM}}$ (New Objective, Woburn, MA, USA; $75 \mu \mathrm{m}$ i.d.) packed to 10 cm with $\mathrm{C} 18$ adsorbent (Vydac, Grace, Deerfield, IL, USA; 218MS $5 \mu \mathrm{m}, 300 \AA$ ); mobile phase $A, 0.5 \%$ acetic acid (HAc) $/ 0.005 \%$ trifluoroacetic acid (TFA); mobile phase B, $90 \%$ acetonitrile/0.5\% HAc/0.005\% TFA; gradient 2 to $42 \%$ $\mathrm{B}$ in $30 \mathrm{~min}$; flow rate, $0.4 \mu \mathrm{l} \cdot \mathrm{min}^{-1}$. MS conditions were: ESI voltage, $2.9 \mathrm{kV}$; isolation window for MS/MS, 3; relative collision energy, $35 \%$; scan strategy, survey scan followed by acquisition of data dependent collision-induced dissociation (CID) spectra of the seven most intense ions in the survey scan above a set threshold. The uninterpreted CID spectra were searched against the NCBInr database [20080310 (6298708 sequences; 2152697077 residues)] by means of Mascot (Matrix Science). Variable modifications considered for the searches included: oxidation of His, Met, and Trp; Trp conversion to kynurenin. Determination of protein identity probabilities were accomplished by Scaffold ${ }^{\mathrm{TM}}$ (Proteome Software, Portland, Oregon, USA). Scaffold verifies peptide identifications assigned by SEQUEST and Mascot using the $\mathrm{X}$ !Tandem database searching program (Craig and Beavis, 2003). Scaffold then probabilistically validates these peptide identifications using PeptideProphet (Keller et al., 2002) and derives corresponding protein probabilities using ProteinProphet (Nesvizhskii et al., 2003).
Pseudo first order kinetics

To determine the apparent pseudo kinetic parameters, the concentration of one substrate was varied and the other substrates' remained constant. The constant concentration for Methyl Red was $20 \mu \mathrm{M}$ and the varying concentrations were $2-20 \mu \mathrm{M}$. For $\mathrm{NADH}$, the constant was $1 \mathrm{mM}$ and varying concentrations were $10-80 \mu \mathrm{M}$. For FMN, constant concentration was $20 \mu \mathrm{M}$ and varying concentrations were 0.5 - $5 \mu \mathrm{M}$. For NADPH the varying concentrations were 1.5 - $10 \mathrm{mM}$. The parameters were determined from the double reciprocal plot using the KaleidaGraph software (Synergy software).

\section{Results}

Enzyme purification

Methyl Red, NADPH and FMN were used for the azoreductase assays during all the purification steps. The initial specific azoreductase activity in the crude cytoplasmic extracts was $0.003 \mathrm{U} \cdot \mathrm{mg}^{-1}$. A combination of hydrophobic interaction, ion-exchange and affinity chromatography was used to purify over 200 - fold of the native azoreductase with a recovery of $10 \%$ (Table I). The protein concentration throughout the purification was determined by the Bradford method.

\section{Native PAGE assay for azoreductase}

The affinity chromatography purified fraction was subjected to electrophoresis at $4{ }^{\circ} \mathrm{C}$ on a discontinuous native PAGE gel (5-12.5\% gradient). The gel was divided in half and each half was incubated separately at room temp with $1 \mathrm{mM} \mathrm{NADH}$ and $2 \mathrm{mM} \mathrm{NADPH}$ to determine which reduced pyridine nucleotide could be utilized as an electron donor. A clearing zone, indicating Methyl Red reduction, was observed in both gels (Fig. $1 \mathrm{~A}$ ). The mobility of the clear zones and the Coomassie Blue stained bands on both gels were the same which suggests the same enzyme could utilize $\mathrm{NAD}(\mathrm{P}) \mathrm{H}$ as the electron donors to reduce Methyl Red (Fig. $1 \mathrm{~A}$ and $\mathrm{B}$ ). 
Table I. Summary of azoreductase purification.

\begin{tabular}{lccccc}
\hline \multicolumn{1}{c}{ Step } & $\begin{array}{c}\text { Total protein } \\
(\mathrm{mg})\end{array}$ & $\begin{array}{c}\text { Total activity } \\
\mathrm{U} / \mathrm{mg} \text { total protein }\end{array}$ & $\begin{array}{c}\text { Specific activity } \\
\mathrm{U} / \mathrm{mg}\end{array}$ & $\begin{array}{c}\text { Yield Purification } \\
(\%)\end{array}$ \\
(fold increase)
\end{tabular}

Note: All enzyme assays were performed with $0.5 \mathrm{mM}$ NADPH, $10 \mu \mathrm{M}$ FMN, $20 \mu \mathrm{M}$ Methyl Red in $50 \mathrm{mM}$ Potassium Phosphate buffer $\mathrm{pH} 7.0$ at $25^{\circ} \mathrm{C}$.

1 unit (U) is defined as the amount of enzyme required to reduce $1 \mu \mathrm{mol}$ of Methyl Red per minute.

\section{Identification of the azoreductase}

The protein band corresponding to the zone of clearing on the native PAGE assay (Fig. 1B) was analyzed by trypsonolysis, MALDI-TOF mass spectrometry and database searching. Using this approach, the predominant protein in the band was identified as a putative acyl carrier protein from $E$. faecalis V583 (AAO82310 from NCBI), yielding a Mascot score of 116 versus the statistical significance threshold of $78(p<0.05)$. An analysis of this hypothetical protein sequence revealed that it was the same azoreductase (AzoA) identified previously by Chen et al. (Chen et al., 2004). All other candidate identifications had scores less than 78 , and were therefore regarded as statistically insignificant. The identification of the azoreductase was based on matching 9 of 16 experimental ion masses which were assigned from the most intense peaks, representing $49 \%$ of the azoreductase sequence (Fig. 2).

To ensure that there were no other proteins in the sample that may have contributed to the azoreductase activity; the trypsin-digested sample was subjected to a more sensitive analysis using nano-bore High Performance Liquid Chromatography in conjunction with Electrospray Tandem Mass Spectrometry (HPLC-ESI-MS/MS).

Tandem mass spectrometry and database searching again identified the putative acyl carrier protein from $E$. faecalis V583 (AAO82310 from NCBI) with search metrics supporting this identification to $100 \%$ probability for the protein and $95 \%$ probability for each peptide (17 unique spectra representing 11 unique peptides which covered $56 \%$ of AzoA sequence) (Fig. 2). LC-MS/MS and a database search at $99.9 \%$ minimum protein and $95 \%$ minimum peptide statistical thresholds identified 16 proteins based on a minimum of 2 peptides, including low levels of keratin contamination. The spectral count indicated that AzoA was the most abundant protein in the sample i.e., 48 AzoAderived spectra in contrast to 22 spectra from hypoxanthineguanine phosphoribosyl transferase and 12 spectra from human keratin which were the next most abundant proteins. No other oxidoreductases were detected in the band of clearing, even when the stringency for identification was relaxed to include proteins associated with or identified by only one peptide, a minimum protein identification threshold of $95 \%$ and a minimum peptide identification threshold of $90 \%$.

\section{Pseudo first order kinetics}

In order to reduce Methyl Red, the enzyme required FMN and $\mathrm{NAD}(\mathrm{P}) \mathrm{H}$. Table II indicates the apparent kinetic parameters for the substrates which were determined from the double reciprocal plot. The $V_{\max }$ values for all substrates were similar, but the catalytic efficiency of AzoA to utilize $\mathrm{NADH}$ over NADPH during Methyl Red reduction was more than 180 - fold (data not shown). The apparent $K_{\mathrm{m}}$ values of $11 \mu \mathrm{M}$ and $82 \mu \mathrm{M}$ for Methyl Red and NADH respectively in this study were lower than $24 \mu \mathrm{M}$ and $140 \mu \mathrm{M}$ respectively as described in the previous study (Chen et al., 2004). FMN had the lowest apparent $K_{m}$ value of $3 \mu \mathrm{M}$ and NADPH had the highest apparent $K_{\mathrm{m}}$ of $15 \mathrm{mM}$. No azoreductase activity

Table II. Apparent kinetic parameters for AzoA.

\begin{tabular}{lcc}
\hline Substrate & $K_{\mathrm{m}}$ & $V_{\max }(\mathrm{U} / \mathrm{mg})$ \\
\hline Methyl Red & $11 \mu \mathrm{M}( \pm 3)$ & $29( \pm 5)$ \\
FMN & $3 \mu \mathrm{M}( \pm 1)$ & $31( \pm 5)$ \\
NADH & $82 \mu \mathrm{M}( \pm 17)$ & $26( \pm 4)$ \\
NADPH & $15 \mathrm{mM} \mathrm{( \pm 3)}$ & $32( \pm 5)$ \\
\hline
\end{tabular}

1 unit $(\mathrm{U})$ is defined as the amount of enzyme required to reduce $1 \mu \mathrm{mol}$ of Methyl Red per minute.

The results are means of three independent experiments ( \pm standard deviation) 


\author{
MSKLLVVKAH PLTKEESRSV RALETFLASY RETNPSDEIE ILDVYAPETN \\ MPEIDEELLS AWGALRAGAA FETLSENQQ KVARFNELTD QFLSADKVVI \\ ANPMWNLNVP TRLKAWVDTI NVAGKTFQYT AEGPKPLTSG KKALHIQSNG
}

GFYEGKDFAS QYIKAILNFI GVDQVDGLFI EGIDHFPDRA EELLNTAMTK

ATEYGKTF

\begin{abstract}
MSKLLVVKAH PLTKEESRSV RALETFLASY RETNPSDEIE ILDVYAPETN
MPEIDEELLS AWGALRAGAA FETLSENQQQ KVARFNELTD QFLSADKVVI

ANPMWNLNVP TRLKAWVDTI NVAGKTFQYT AEGPKPLTSG KKALHIQSNG

GFYEGKDFAS QYIKAILNFI GVDQVDGLFI EGIDHFPDRA EELLNTAMTK
\end{abstract}

ATEYGKTF

Fig. 2 Sequence coverage of AzoA by MALDI-TOF (underlined) and LC-MS/MS (shaded)

was observed when the sulfonated azo dyes, Direct Blue 15 and Tartrazine, were used as substrate. Methyl Red was not reduced in the control reaction which contained NADPH and the azo dye but no enzyme. An additional control which contained FMN, NADPH and Methyl Red showed no spontaneous reduction of the dye. The same results were observed when NADH was used in the control experiments instead of NADPH. These control experiments confirm that the reduction of Methyl Red is associated with AzoA and not due to the instability of the dye under the reaction conditions as well as non-enzymatic reactions.

It is important to note that the aforementioned definition of specific activity was in molar quantity $\left(\mu \mathrm{mol} . \mathrm{min}^{-1} \cdot \mathrm{mg}^{-1}\right.$ ) while the specific activity as defined by the earlier study (Chen et al., 2004) was in molar concentration ( $\mu$ M.min $\left.{ }^{-1} \cdot \mathrm{mg}^{-1}\right)$. Thus, when recalculating the apparent $V_{\max }$ of AzoA for Methyl Red $\left(89.2 \mu \mathrm{M} . \mathrm{min}^{-1} . \mathrm{mg}^{-1}\right)$ from the earlier study according to the current definition, the value in the $2 \mathrm{~mL}$ reaction mixture would be $0.18 \mu \mathrm{mol} . \mathrm{min}^{-1} . \mathrm{mg}^{-1}$. In comparison, the apparent $V_{\max }$ for Methyl Red in the present study was $29( \pm 5) \mu \mathrm{mol} . \mathrm{min}^{-1} . \mathrm{mg}^{-1}$ (Table II); hence, the value obtained from the present study was more than 150-fold higher than the previous estimation of $V_{\max }$ for AzoA.

Table III compares the kinetic parameters for azoreductase between the heterologous source $(E$. coli) and the natural source ( $E$. faecalis). The catalytic efficiency $\left(K_{\text {cat }} \cdot K_{\mathrm{m}}{ }^{-1}\right)$ clearly indicates that the $E$. faecalis-purified AzoA (1.9 $\left.\mu \mathrm{M}^{-1} . \mathrm{s}^{-1}\right)$ is 380 -fold higher than the E. coli-purified AzoA $\left(0.005 \mu \mathrm{M}^{-1} . \mathrm{s}^{-1}\right)$ and approximately 190 and 11 -fold higher than the azoreductases from Staphylococcus aureus and Pseudomonas aeruginosa respectively.

\section{Discussion}

The structure and function of azoreductases from microorganisms is not fully understood as these enzymes have specific and broad specificities. In addition, the very low homology at the enzymes' primary structure level makes it difficult to classify and assess its evolutionary progression. Current classification schemes use the enzymes preference for an electron donor, which are flavin-dependent NADH only, NADPH only, and both.

Previous work (Walker et al., 1971) demonstrated that $E$. faecalis cell extracts could utilize both $\mathrm{NAD}(\mathrm{P}) \mathrm{H}$ as electron donors for azoreductase activity, although activity was much greater for NADH compared to NADPH . Our work (Punj and John, 2008) also supported the activity for both NADH and NADPH from $E$. faecalis. In comparison, another study showed heterologously expressed AzoA from E. faecalis utilized only $\mathrm{NADH}$ for azo dye reduction. It was reasoned that there may be other azoreductases present in wild-type $E$. faecalis or altered activity in a heterologous system.

Using a 3-step purification process, a polyacrylamide-based enzyme assay and mass spectrometry, we showed that AzoA from $E$. faecalis was indeed responsible for utilizing both $\mathrm{NADH}$ and NADPH for activity. Hence, we conclude that $A z o A$ is an $N A D(P) H$ dependent enzyme and can thus be reclassified as an NADH and NADPH dependent azoreductase. The previous study on heterologously expressed AzoA by Chen's group also utilized a similar 3-step purification process; but the NADPH activity was not observed, possibly due to the overall low activity of the enzyme from the heterologous system. As shown in Table III, AzoA purified from its natural source reduced Methyl Red with much greater efficiency than other flavindependent azoreductases, including AzoA purified from a 
Table III

\begin{tabular}{lcccc}
\hline Organism & \multicolumn{4}{c}{ Methyl Red } \\
\cline { 2 - 5 } Reference & $K_{\mathrm{m}}$ & $V_{\max }$ & $K_{\text {cat }} K_{\mathrm{m}}{ }^{-1}$ \\
& $(\mu \mathrm{M})$ & $\left(\mu \mathrm{mol} \cdot \mathrm{min}^{-1} \cdot \mathrm{mg}^{-1}\right)$ & $\left(\mu \mathrm{M}^{-1} \cdot \mathrm{s}^{-1}\right)$ & \\
\hline E. faecalis $^{\mathrm{a}}$ & 11 & 29 & 1.9 & This study \\
$\begin{array}{l}\text { S. aureus } \\
\text { 2005 }\end{array}$ & 57 & 0.41 & 0.01 & Chen H. et al., \\
$\begin{array}{l}P . \text { aeruginosa }^{\mathrm{b}} \\
\text { 2007 }\end{array}$ & 76 & 0.34 & 0.17 & Wang C.J. et al, \\
$\begin{array}{l}\text { E. faecalis } \\
\text { 2004 }\end{array}$ & 24 & 0.18 & & Chen H. et al., \\
\hline
\end{tabular}

\author{
a - native source \\ $\mathrm{b}$ - heterologous source (E. coli) \\ For comparison and consistency, the $V_{\max }$ values were converted to units, $\mu$ mol.min ${ }^{-1} \cdot \mathrm{mg}^{-1}$ \\ The molecular weight of the azoreductase used for the calculation of $K_{\text {cat }}$ was: E. faecalis \\ AzoA (43,000 Da) and S. aureus Azo1 (85,000 Da). The catalytic efficiency $K_{\text {cat }} \cdot K_{\mathrm{m}}{ }^{-1}$ \\ value for $P$. aeruginosa, paAzoR1 was used directly for the original article.
}

heterologous source. These results indicate that the true catalytic efficiency of the azoreductases from $S$. aureus and $P$. aeruginosa may be underestimated since they were purified and characterized from a heterologous system.

The characterization of the native purified $A z o A$ supported the association of the FMN and the NAD(P) $\mathrm{H}$ binding pocket i.e., the reduction of the dye occurs by the transfer of electron from $\mathrm{NAD}(\mathrm{P}) \mathrm{H}$ via FMN (Chen et al., 2004; Nakanishi et al., 2001). It was determined that externally added FMN was essential for activity of AzoA, most likely due to the FMN moieties being disassociated from the holoenzyme during the hydrophobic-column protein purification step. Chen's group also showed the disassociation of the FMN prosthetic group from the AzoA holoenzyme after hydrophobic chromatography. Our finding of FMN association is also supported by the crystal structure information for azoreductases possessing a flavodoxin_2 domain (PF02525) such as AzoA, AzoR and paAzoR1 (Ito et al., 2006; Wang et al., 2007).

Analysis of the active sites, based on the crystal structures of E. coli AzoR (PDB code: 1V4B) (Ito et al., 2006), $P$. aeruginosa paAzoR1 (PDB code: 2v9c) (Wang et al., 2007), human $\mathrm{FAD}$-dependent $\mathrm{NAD}(\mathrm{P}) \mathrm{H}$ :quinine oxidoreductase NQO1 (PDB code: 1DXO) (Faig et al., 2000) and E. faecalis AzoA (PDB code: 2HPV) (Liu et al., 2007) showed that they are highly conserved which supports the presence of a $\mathrm{NAD}(\mathrm{P}) \mathrm{H}$ binding pocket. In addition, the active site of NQO1, reveals that the $\mathrm{NH}$ in the main chain of $\mathrm{Phe}^{232}$ forms a hydrogen bond with an oxygen of the phosphate moiety in NADPH while this bond is not formed in the presence of NADH ( $\mathrm{Li}$ et al., 1995). Finally, it has also been suggested that there maybe conformational flexibility in the active site which could lead to binding of both $\mathrm{NADH}$ as well as NADPH (Wang et al., 2007).
In conclusion, the azoreductase AzoA isolated from $E$. faecalis and tested under native gel conditions can utilize $\mathrm{NAD}(\mathrm{P}) \mathrm{H}$ as an electron donor but its preference is for $\mathrm{NADH}$. The specific activity is more than a 150 -fold higher when NADH is used as the electron donor as compared to its activity when expressed heterologously in $E$. coli. Thus, the azoreductase AzoA purified from $E$. faecalis will provide better activity analysis that is more reflective of xenobiotic degradation within the intestine. Although the $E$. coli-based over-expression system is a fast and efficient process to characterize azoreductases, it may not reflect the activity of the azoreductase that is inherently present in its natural source. To this end, the combination of column chromatography and the polyacrylamide-based native gel assay coupled with mass spectrometry is a useful method to isolate and identify azoreductases from their native source.

\section{Acknowledgements}

The authors would like to thank the Biochemistry Core Facility at Oklahoma State University, Stillwater, OK, USA for the MALDI-TOF analyses and the Mass Spectrometry Laboratory of the University of Texas Health Science Center at San Antonio, TX, USA for the HPLC-ESI-MS/MS analyses. The authors are also grateful to Dr. Steve Hartson for helpful discussions on the mass spectrometry data.

\section{References}

Abraham KJ, J. G. (2007). Development of a Classification Scheme using a Secondary and Tertiary Amino Acid Analysis of Azoreductase Gene. Journal of Medical and Biological Sciences 1, 1-5.

Asad, S., Amoozegar, M. A., Pourbabaee, A. A., Sarbolouki, M. N., and Dastgheib, S. M. (2007). Decolorization of textile azo dyes by newly isolated halophilic and halotolerant bacteria. Bioresour Technol 98, 2082-2088.

Blumel, S., Knackmuss, H. J., and Stolz, A. (2002). Molecular 
cloning and characterization of the gene coding for the aerobic azoreductase from Xenophilus azovorans KF46F. Appl Environ Microbiol 68, 3948-3955.

Blumel, S., and Stolz, A. (2003). Cloning and characterization of the gene coding for the aerobic azoreductase from Pigmentiphaga kullae K24. Appl Microbiol Biotechnol 62, 186-190.

Chen, H. (2006). Recent advances in azo dye degrading enzyme research. Curr Protein Pept Sci 7, 101-111.

Chen, H., Hopper, S. L., and Cerniglia, C. E. (2005). Biochemical and molecular characterization of an azoreductase from Staphylococcus aureus, a tetrameric NADPH-dependent flavoprotein. Microbiology 151, 1433-1441.

Chen, H., Wang, R. F., and Cerniglia, C. E. (2004). Molecular cloning, overexpression, purification, and characterization of an aerobic FMN-dependent azoreductase from Enterococcus faecalis. Protein Expr Purif 34, 302-310.

Chung, K. T., Stevens, S. E., Jr., and Cerniglia, C. E. (1992). The reduction of azo dyes by the intestinal microflora. Crit Rev Microbiol 18, 175-190.

Craig, R., and Beavis, R. C. (2003). A method for reducing the time required to match protein sequences with tandem mass spectra. Rapid Commun Mass Spectrom 17, 2310-2316.

Faig, M., Bianchet, M. A., Talalay, P., Chen, S., Winski, S., Ross, D., and Amzel, L. M. (2000). Structures of recombinant human and mouse $\mathrm{NAD}(\mathrm{P}) \mathrm{H}$ :quinone oxidoreductases: species comparison and structural changes with substrate binding and release. Proc Natl Acad Sci U S A 97, 3177-3182.

Ghosh, D. K., Mandal, A., and Chaudhuri, J. (1992). Purification and partial characterization of two azoreductases from Shigella dysenteriae type 1. FEMS Microbiol Lett 77, 229-233.

Ito, K., Nakanishi, M., Lee, W. C., Sasaki, H., Zenno, S., Saigo, K., Kitade, Y., and Tanokura, M. (2006). Threedimensional structure of AzoR from Escherichia coli. An oxidereductase conserved in microorganisms. J Biol Chem 281, 20567-20576.

Keller, A., Nesvizhskii, A. I., Kolker, E., and Aebersold, R. (2002). Empirical statistical model to estimate the accuracy of peptide identifications made by MS/MS and database search. Anal Chem 74, 5383-5392.
Laemmli, U. K. (1970). Cleavage of Structural Proteins during the Assembly of the Head of Bacteriophage T4. Nature 227, 680-685.

Li, R., Bianchet, M. A., Talalay, P., and Amzel, L. M. (1995). The three-dimensional structure of $N A D(P)$ $\mathrm{H}$ :quinone reductase, a flavoprotein involved in cancer chemoprotection and chemotherapy: mechanism of the two-electron reduction. Proc Natl Acad Sci U S A 92, 8846-8850.

Liu, Z. J., Chen, H., Shaw, N., Hopper, S. L., Chen, L., Chen, S., Cerniglia, C. E., and Wang, B. C. (2007). Crystal structure of an aerobic FMN-dependent azoreductase (AzoA) from Enterococcus faecalis. Arch Biochem Biophys 463, 68-77.

Nakanishi, M., Yatome, C., Ishida, N., and Kitade, Y. (2001). Putative ACP phosphodiesterase gene (acpD) encodes an azoreductase. J Biol Chem 276, 46394-46399.

Nesvizhskii, A. I., Keller, A., Kolker, E., and Aebersold, R. (2003). A statistical model for identifying proteins by tandem mass spectrometry. Anal Chem 75, 4646-4658.

Punj, S., and John, G. H. (2008). Physiological Characterization of Azo Dye Reduction in Enterococcus faecalis. Microbial Ecology in Health and Disease. iFirst, 1-9. DOI: $10.1080 / 08910600802169630$

Stoddart, A. M., and Levine, W. G. (1992). Azoreductase activity by purified rabbit liver aldehyde oxidase. Biochem Pharmacol 43, 2227-2235.

Stolz, A. (2001). Basic and applied aspects in the microbial degradation of azo dyes. Appl Microbiol Biotechnol 56, 69-80.

Walker, R., Gingell, R., and Murrells, D. F. (1971). Mechanisms of azo reduction by Streptococcus faecalis. I. Optimization of assay conditions. Xenobiotica 1, 221-229.

Wang, C. J., Hagemeier, C., Rahman, N., Lowe, E., Noble, M., Coughtrie, M., Sim, E., and Westwood, I. (2007). Molecular cloning, characterisation and ligandbound structure of an azoreductase from Pseudomonas aeruginosa. J Mol Biol 373, 1213-1228.

Zbaida, S., and Levine, W. G. (1990). Characteristics of two classes of azo dye reductase activity associated with rat liver microsomal cytochrome P450. Biochem Pharmacol 40, 2415-2423. 


\section{Further Reading}

Caister Academic Press is a leading academic publisher of advanced texts in microbiology, molecular biology and medical research. Full details of all our publications at caister.com

- MALDI-TOF Mass Spectrometry in Microbiology Edited by: M Kostrzewa, S Schubert (2016) www.caister.com/malditof

- Aspergillus and Penicillium in the Post-genomic Era Edited by: RP Vries, IB Gelber, MR Andersen (2016) www.caister.com/aspergillus2

- The Bacteriocins: Current Knowledge and Future Prospects Edited by: RL Dorit, SM Roy, MA Riley (2016)

www.caister.com/bacteriocins

- Omics in Plant Disease Resistance Edited by: V Bhadauria (2016) www.caister.com/opd

- Acidophiles: Life in Extremely Acidic Environments Edited by: R Quatrini, DB Johnson (2016) www.caister.com/acidophiles

- Climate Change and Microbial Ecology: Current Research and Future Trend

Edited by: J Marxsen (2016)

www.caister.com/climate

- Biofilms in Bioremediation: Current Research and Emerging Technologies

Edited by: G Lear (2016)

www.caister.com/biorem

- Microalgae: Current Research and Applications Edited by: MN Tsaloglou (2016) www.caister.com/microalgae

- Gas Plasma Sterilization in Microbiology: Theory, Applications, Pitfalls and New Perspectives Edited by: H Shintani, A Sakudo (2016) www.caister.com/gasplasma

- Virus Evolution: Current Research and Future Directions Edited by: SC Weaver, M Denison, M Roossinck, et al. (2016) www.caister.com/virusevol

- Arboviruses: Molecular Biology, Evolution and Control Edited by: N Vasilakis, DJ Gubler (2016) www.caister.com/arbo

- Shigella: Molecular and Cellular Biology Edited by: WD Picking, WL Picking (2016) www.caister.com/shigella

-Aquatic Biofilms: Ecology, Water Quality and Wastewater Treatment

Edited by: AM Romaní, H Guasch, MD Balaguer (2016)

www.caister.com/aquaticbiofilms

- Alphaviruses: Current Biology

Edited by: S Mahalingam, L Herrero, B Herring (2016)

www.caister.com/alpha

- Thermophilic Microorganisms

Edited by: F Li (2015)

www.caister.com/thermophile
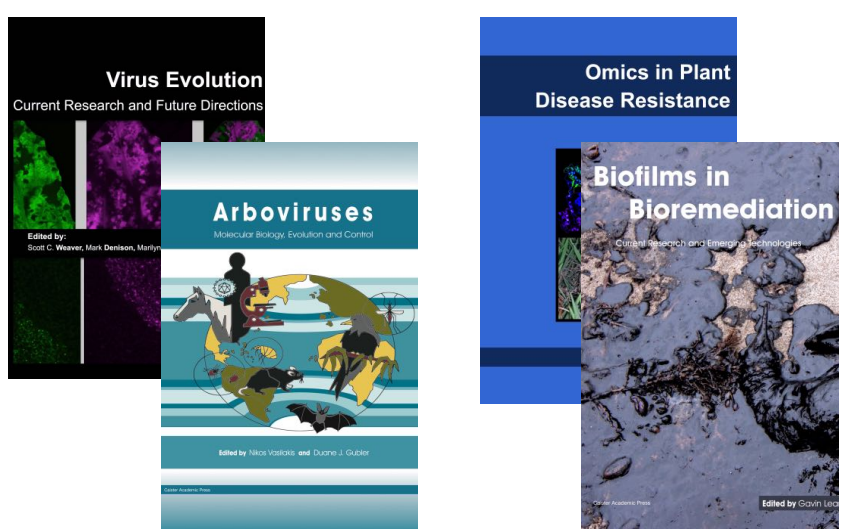
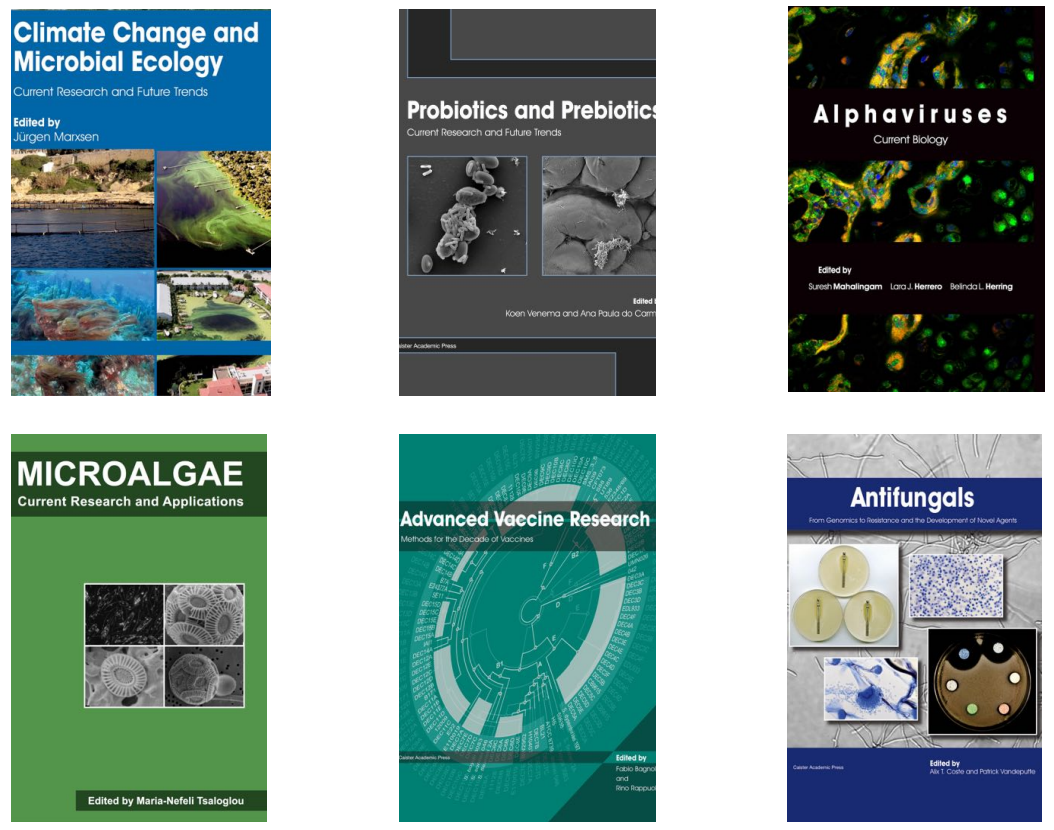

- Flow Cytometry in Microbiology: Technology and Applications Edited by: MG Wilkinson (2015) www.caister.com/flow

- Probiotics and Prebiotics: Current Research and Future Trends Edited by: K Venema, AP Carmo (2015) www.caister.com/probiotics

- Epigenetics: Current Research and Emerging Trends Edited by: BP Chadwick (2015) www.caister.com/epigenetics2015

- Corynebacterium glutamicum: From Systems Biology to Biotechnological Applications

Edited by: A Burkovski (2015)

www.caister.com/cory2

- Advanced Vaccine Research Methods for the Decade of Vaccines

Edited by: F Bagnoli, R Rappuoli (2015)

www.caister.com/vaccines

- Antifungals: From Genomics to Resistance and the Development of Novel Agents

Edited by: AT Coste, P Vandeputte (2015)

www.caister.com/antifungals

- Bacteria-Plant Interactions: Advanced Research and Future Trends Edited by: J Murillo, BA Vinatzer, RW Jackson, et al. (2015) www.caister.com/bacteria-plant

\section{- Aeromonas}

Edited by: J Graf (2015)

www.caister.com/aeromonas

- Antibiotics: Current Innovations and Future Trends

Edited by: S Sánchez, AL Demain (2015)

www.caister.com/antibiotics

- Leishmania: Current Biology and Contro Edited by: S Adak, R Datta (2015) www.caister.com/leish2

- Acanthamoeba: Biology and Pathogenesis (2nd edition) Author: NA Khan (2015)

www.caister.com/acanthamoeba2

- Microarrays: Current Technology, Innovations and Applications Edited by: Z He (2014)

www.caister.com/microarrays2

- Metagenomics of the Microbial Nitrogen Cycle: Theory, Methods and Applications

Edited by: D Marco (2014)

www.caister.com/n2 